staff of the Department of Animal Genetics, Madras Veterinary College, for statistical analysis.

\section{O. S. REDDI}

M. Sanjeeva Rao

\section{Radiation Genetics Project, Osmania University,} Hyderabad.

${ }^{2}$ Baboock, E. B., and Collins, J. L., Proc. U.S. Nat. Acad. Sci., 15, 623 (1929).

${ }^{2}$ Babcoek, E. B., and Collins, J. L., Nature, 124, 227 (1929).

${ }^{3}$ Hanson, F. B., and Heys, F., Science, 71, 43 (1930).

4 Jollos, V., Genetics, 24, 113 (1939).

${ }^{5}$ Muller, H. J., Pub. Acad. Sci. U.S.S.R., 569 (1935) (in Russian).

- Delbrück, M., and Timof́eff-Ressovsky, N. W., Nature, 137, 358 (1936).

'Friesen, H., C.R. Acad. Sci., U.R.S.S., 1, 183 (1936).

Rajewsky, B. N., and Timoféeff-Ressovsky, N. W., Z. Indukt. Abstamm. Vererbungslehre, 77, 488 (1939).

'Pipkin, S., Bedichek, and Sullivan, W. N., Aerospace Med., 30 (8), 585 (1959).

${ }^{10}$ Gokhale, G. S., and Kunte, P. K. (personal communication).

\section{BIOLOGY}

\section{Polar Transport of a Kinin, Benzyladenine}

From limited experimental evidence it has been assumed that kinins are relatively immobile in plants'. When the synthetic kinin, kinetin, is applied to the surface of a leaf its effects in retarding senescence or acting as a locus for the accumulation of metabolites are restricted to the treated parts ${ }^{2}$. A direct investigation of the movement of isotopically labelled benzyladenine within petiole segments of Phaseolus vulgaris now reveals that this kinin is not only transported readily through the tissues, but that the movement is also basipetally polar. Furthermore, the total amount transported is enhaneed by the addition of indolyl-3-acetic acid (IAA).

The methods of studying the movement of the kinin in segments cut from elongating petioles of young primary leaves of $P$. vulgaris were similar to those described by $\mathrm{McCready}^{3}$, and are based on the classical methods of Went ${ }^{4}$. The kinin used was adenine-8- ${ }^{14} \mathrm{C}$-labelled benzyladenine $\left(\mathrm{BA}^{-14} \mathrm{C}\right)$, of specifie activity $5.05 \mu \mathrm{c} . / \mathrm{mg}$, and was a gift from Dr. J. van Overbeek of the Shell Development Co., Modesto, California. Agar gels of 1.5 per cent containing either $\mathrm{BA}^{-14} \mathrm{C}$ at $37 \mathrm{mg} / \mathrm{l}$. or a mixture of the $\mathrm{BA}^{-14} \mathrm{C}$ together with IAA at $2 \mathrm{mg} / \mathrm{l}$. were sectioned into blocks of $23 \mu \mathrm{l}$. volume. A donor block containing the $\mathrm{BA}^{-14} \mathrm{C}$ or $\mathrm{BA}^{-14} \mathrm{C}$ with IAA was applied to one end of a petiole segment of length $5.4 \mathrm{~mm}$. A plain agar receiver block was applied to the other end. A segment from the petiole of one primary leaf was used for basipetal transport, and the appropriate radioactive donor block was applied to the physiologically apical end. For acropetal transport, the radioactive donor block was applied to the physiologically basal end of a comparable segment from the petiole of the second primary leaf. Each treatment comprised 16 segments, and at the end of the experimental period the 16 donor or receiver blocks were pooled for radioactive assay by the method deseribed by MeCready ${ }^{5}$.

The results in Table 1 show that when $\mathrm{BA}^{-14} \mathrm{C}$ is supplied alone in the donor blocks, the transport of radio-

Table 1. Basipetal AND ACropetal Transport of the Kinin, BenzyLADENINB, ALONE AND IN COMBINATION WITH INDOLYL-3-ACETIC ACID, IN ADENINB, ALONE AND IN COMBINATION WITH INDOLY

\begin{tabular}{|c|c|c|c|c|c|}
\hline \multirow[b]{2}{*}{ 'Treatment } & \multirow[b]{2}{*}{$\begin{array}{c}\text { Direction } \\
\text { of } \\
\text { transport }\end{array}$} & \multirow[b]{2}{*}{$\begin{array}{c}\text { Counts/ } \\
\text { min } \\
\text { supplied }\end{array}$} & \multicolumn{3}{|c|}{$\begin{array}{l}\text { Distribution of radioactivity } \\
\text { after } 24 \mathrm{~h} \text { (counts/min) }\end{array}$} \\
\hline & & & $\begin{array}{l}\text { Donor } \\
\text { blocks }\end{array}$ & Uptake & $\begin{array}{c}\text { Receiver } \\
\text { blocks }\end{array}$ \\
\hline $37 \mathrm{mg} / \mathrm{l} . \mathrm{BA}^{-14} \mathrm{C}$ & Basipetal & 0787 & 3,688 & 6,099 & 229 \\
\hline $37 \mathrm{mg} / 1 . \mathrm{BA}^{-14} \mathrm{C}$ & $\begin{array}{l}\text { Acropetal } \\
\text { Basipetal }\end{array}$ & & $\begin{array}{l}4,180 \\
4,390\end{array}$ & $\begin{array}{l}5,607 \\
5,554\end{array}$ & $\begin{array}{r}61 \\
524\end{array}$ \\
\hline $\begin{array}{c}\text { plug } \\
2 \mathrm{mg} / 1 . \mathrm{IAA}\end{array}$ & Acropetal & 9,944 & 4,378 & 5,566 & 46 \\
\hline
\end{tabular}

activity through a segment in the basipetal direction is at least three times greater than that in the acropetal direction after $24 \mathrm{~h}$. When $\mathrm{BA}^{-14} \mathrm{C}$ is supplied together with IAA in the donor blocks, the total basipetal transport is increased more than 2-fold, with no accompanying increase in acropetal transport. The radioactivity in the receiver blocks has been recovered by suitable extraction procedures and has been shown by electrophoretic separation to be indistinguishable from the $\mathrm{BA}^{-14} \mathrm{C}$ originally supplied.

It must be concluded, therefore, that the transport of the synthetic kinin, benzyladenine, is basipetally polar in the young petioles of bean. The fact that the amount of kinin that is transported is increased by the concomitant application of indolyl-3-acetic acid, the movement of which is itself polar, suggests that the transport of these substances may be interdependent.

These new facts concerning the movement of growth regulatory substances in plant tissues have important implications in the interpretation of the hormonal control of growth processes in the plant.

We thank Prof. G. E. Blackman for encouragement, and Dr. C. C. McCready for providing facilities.

DAPHNE J. Osborne M. KAY BLACK

Agricultural Research Council

Unit of Experimental Agronomy,

Department of Agriculture, Oxford.

1 Thimann, K. V., Ann. Rev. Plant Physiol., 14, 1 (1963).

${ }^{2}$ Mothes, K., Engelbrecht, L., and Kulajewa, O., Flora (Jena), 147, 445 (1959). ${ }^{3}$ McCready, C. C., New Phytol., 62, 3 (1963).

4 Went, F. W., Rec. Trav. bot. néerl., 25, 1 (1928).

${ }^{5}$ McCready, C. C., Nature, 181, 1406 (1958).

\section{Decreasing Transpiration of Field Plants by Chemical Closure of Stomata}

Chemicals which close stomata have been described by Zelitch ${ }^{1}$. When sprayed on leaf surfaces, the compounds decrease transpiration and photosynthesis of detached leaves $^{2}$ and of maize plants in soil ${ }^{3}$ by increasing the diffusion resistance of stomata. When sprayed on intact tobacco plants in the greenhouse ${ }^{2}$ or on sunflowers growing in bins of soil outdoors ${ }^{3}$, the compounds reduced the loss of water from the soil. It remained to demonstrate the effect of chemical closure of stomata on transpiration by a population of plants in the field.

Two field balances of the type described by Morris ${ }^{4}$ were installed in a level 20 -acre field at Rothamsted and are distinguished as 'east' and 'west', about 30 and $90 \mathrm{~m}$ respectively from the eastern and western boundaries. They are about $180 \mathrm{~m}$ from each other and $180 \mathrm{~m}$ from the southern boundary. Each balance carries a soil pan, $60 \mathrm{~cm}$ deep and $2 \mathrm{~m}^{2}$ in area, sunk in a brick-lined pit to be flush with the field. In 1961 the pans were filled with soil from the surroundings, and in April 1963 they were sown by hand with barley (var. Proctor) when the whole area was machine drilled. Compound fertilizer $(20: 10: 10)$ was applied at 3 cwt./acre. Weight changes of the soil-pan contents were recorded continuously and interpreted as evaporation, rainfall, or dew by reference to a recording rain-gaugo. Daily totals of evaporation $E_{e}$ and $E_{w}$ from the east and west balances were measured to $30 \%$, except when the record was confused by rain.

The behaviour of stomata was observed with a small portablo porometer ${ }^{3}$. Essentially, as air escapes from the porometer and through the leaf, pressure falls logarithmically with time. From the slope of the logarithmic decrease is subtracted the slope of $0.008 \mathrm{sec}^{-1}$ observed with an impervious film in the meter. The reciprocal of the corrected slope is considered the sum of resistances $S_{1}$ and $S_{2}$ of two porous epidermises and the resistarece $M$ of the mesophyll. $M$ was estimated as $5 \cdot 7 \mathrm{sec}$, the minimum 